\title{
Vi er barn av Kongo \\ Vi ønsker fred, skoler og sykehus
}

Engelsk oversettelse på www.tidsskriftet.no
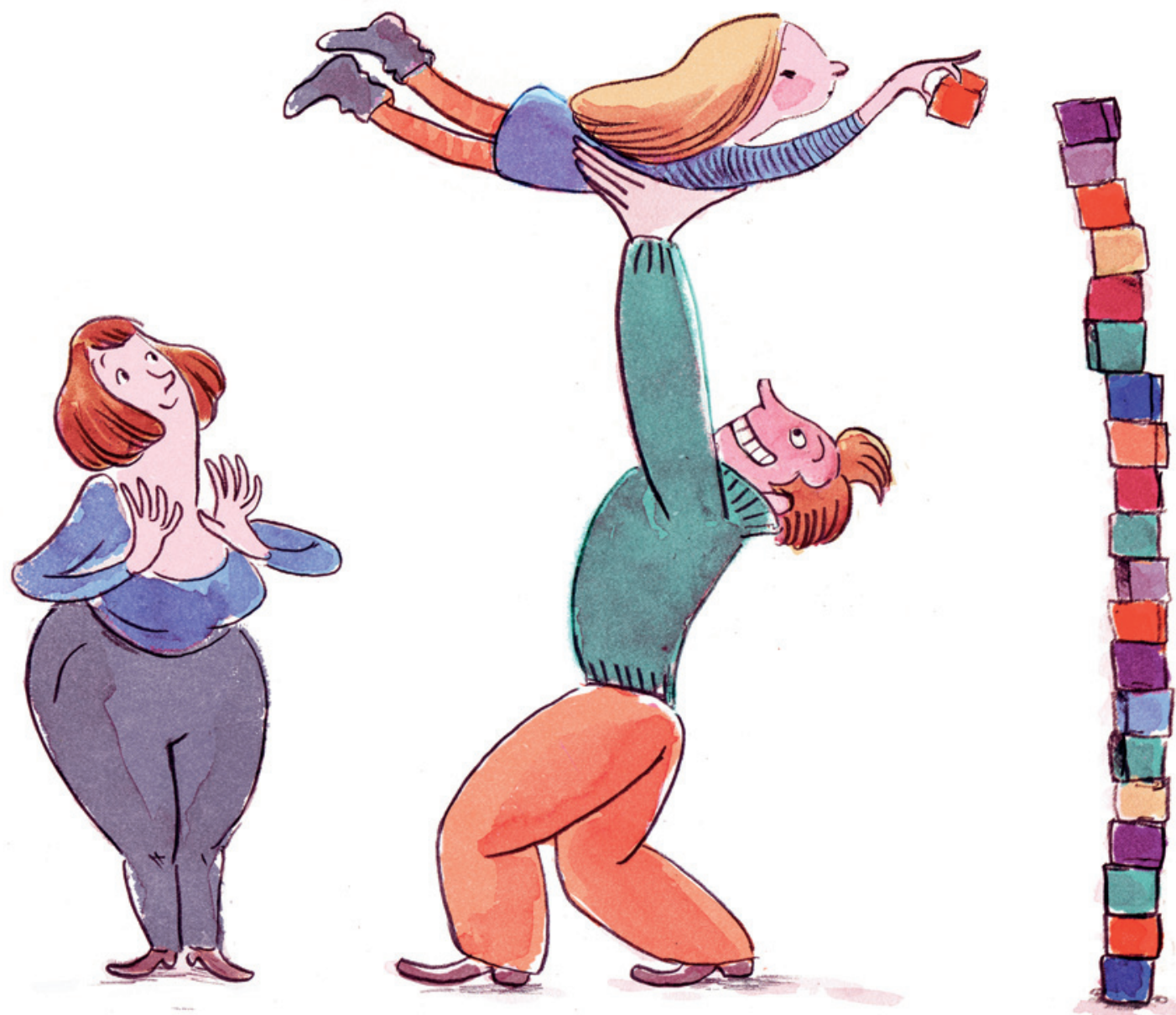

Illustrasjon @ Åshild Irgens

\section{Velferdsstatens dilemma}

Vi er barn av Norge

Vi har fred, skoler og sykehus

Barnehager, trygge lekeplasser og alt vi trenger til livets opphold

De fleste av oss i overflod

Likevel syter og klager vi

Sammen med svenskene topper vi listen Over barn med dårligst selvopplevd helse Vi har mest hodepine, magesmerter søvnproblemer og følelsen av å være nedfor

Hva feiler det oss

Tåler vi ikke velferdstatens goder

Eller er det våre foreldre som ikke gjør det?

De topper jo listen over høyt sykefravær!
Første leveår er fylt av varm omsorg Men allerede i småbarnsalderen kommer foreldrenes frykt for at vi ikke skal klare oss i konkurransesamfunnet

Vi må stimuleres - for enhver pris Det føles som et press til å bli superbarn Gode på skolen, $\mathrm{i}$ idrett sommer som vinter og i minst en kunstart sang, dans, fiolin eller piano

Hver dag er belagt ingen tid til selvplanlagt fritid det som var foreldregenerasjonens viktigste læring

Blir vi generasjonen uten barndom?

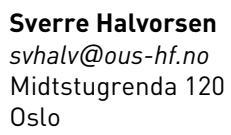

Sverre Halvorsen (f. 1925) er pensjonert barnelege og tidligere professor i pediatri ved Universitetet i Oslo.

Ingen oppgitte interessekonflikter.

Mottatt 11.1. 2012 og godkjent 19.1. 2012. Medisinsk redaktør Erlend Hem. 